African Crop Science Journal by African Crop Science Society is licensed under a Creative Commons Attribution 3.0 Uganda License. Based on a work at www.ajol.info/ and www.bioline.org.br/cs DOI: https://dx.doi.org/10.4314/acsj.v28i1.10S

\title{
ROLE OF NETWORKING CAPABILITY, SOCIO-ECONOMIC AND INSTITUTIONAL CHARACTERISTICS ON ADOPTION TENDENCIES OF CLEAN SEED POTATO AGRI-ENTERPRISES IN CENTRAL RIFT VALLEY, KENYA
}

\author{
M.J. ONG'AYO, E.O. GIDO, O.I. AYUYA, M. MWANGI ${ }^{1}$ and A.M. KIBE ${ }^{1}$ \\ Department of Agricultural Economics and Agribusiness Management, Egerton University, \\ P. O. Box 536-20115, Nakuru, Kenya \\ ${ }^{1}$ Department of Crops Horticulture and Soils, Egerton University, P. O. Box 536-20115, \\ Nakuru, Kenya \\ Corresponding author: mercyjerusa@ rocketmail.com
}

\begin{abstract}
Even though quality of seed is a major yield determinant in potato (Solanum tuberosum L.) production and global food security, inadequate availability of and access to high quality (certified) seed is a major challenge to potato producers in Sub-Saharan Africa. The objective of this study was to examine farmer's adoption tendency towards decentralised clean seed potato multiplication agri-enterprise (CSPMAE) in Central Rift Valley, Kenya, which aids in implementation of stage matched entrepreneurial interventions. A cross-sectional survey was conducted using a semi-structured questionnaire on 54 seed potato producers and 192 non-seed potato producers, through multistage sampling. Ordered logistic regression analysis, based on the trans-theoretical model, revealed that household head, partner knowledge, gender, land size allocated for potato production, level of education, ownership of transport and/or storage facilities, frequency of interaction with certified seed potato producers and agricultural extension officers influenced adoption tendencies of CSPMAE, positively and significantly. Seed potato value chain stakeholder platforms, development workers and donors should prioritise their support for clean seed agri-enterprises to farmers with such traits. This is likely to lead to increased supply of access to clean seed, thereby improving potato yields in Kenya.
\end{abstract}

Key Words: Solanum tuberosum, stakeholder platforms, Sub-Saharan Africa

\section{RÉSUMÉ}

Même si la qualité des semences est le déterminant majeur du rendement dans la production de pommes de terre (Solanum tuberosum L.) et la sécurité alimentaire mondiale, la disponibilité et l'accès inadéquats aux semences de haute qualité (certifiées) constituent un défi majeur pour les producteurs de pommes de terre en Afrique sub-saharienne. L'objectif de cette étude était d'examiner la tendance à l'adoption par les agriculteurs de l'agro-entreprise décentralisée de multiplication des semences de pommes de terre propre (CSPMAE) dans la vallée centrale du Rift, au Kenya, qui facilite la mise en œuvre d'interventions entrepreneuriales assorties par étapes. Une enquête transversale a été menée à 
l'aide d'un questionnaire semi-structuré sur 54 producteurs des semences de pommes de terre et 192qui ne sont pas producteurs des semences de pommes de terre, par échantillonnage à plusieurs degrés. Une analyse de régression logistique ordonnée, basée sur le modèle transthéorique, a révélé que le chef de ménage, les connaissances des partenaires, le sexe, la taille des terrains allouées à la production de pommes de terre, le niveau d'éducation, la propriété des installations de transport et / ou de stockage, la fréquence d'interaction avec les semence de pomme de terre certifies, les producteurs et les agents de vulgarisation agricole ont influencé positivement et significativement les tendances d'adoption du CSPMAE. Les plateformes des parties prenantes de la chaîne de valeur des semences de pommes de terre, les agents de développement et les bailleurs de fonds devraient accorder la priorité à leur soutien aux agro-entreprises de semences propres aux agriculteurs ayant de tels traits. Cela devrait entraîner une augmentation de l'accès à des semences propres, améliorant ainsi les rendements de pommes de terre au Kenya.

Mots Clés: Solanum tuberosum, plateformes des parties prenantes, Afrique sub-saharienne

\section{INTRODUCTION}

Potato (Solanum tuberosum L.) is a major food security tuber crop in Kenya, ranking second after maize (Zea mays L.) (GoK, 2017). Quality seed potato is among the vital inputs with potential to stimulate agricultural productivity, economic growth, and entrepreneurial opportunities, particularly in the central Rift Valley region of the country (Louwaars and De Boef, 2012). According to Chindi et al. (2017), a seed system that ensures seed security to farmers is essential in realising the potential for potato production and its contribution to food security.

Despite the significance of the potato subsector in the country, its yields per unit area have declined way below potential, with poor quality seed being a major factor for this trend (Demo et al., 2016; KEPHIS, 2016). Nearly $95 \%$ of smallholder potato farmers use degenerated seed due to inadequate supply and in-accessibility to quality seed in the country (McGuire and Sperling, 2016; NPCK, 2020). Although the formal sector is mandated to supply certified seed, its production is far below the annual demand exhibited by 600,000 to 800,000 potato farmers. Only 2 to $2.6 \%$ of these farmers access certified seed. Additionally, its centralised and oligopoly nature leads to high transactional costs and pricing of certified seed, which limits resource constrained farmers from accessing certified seed (Okello et al., 2017).

Despite a few collaborative efforts and interventions by the donor community to increase supply of certified seed, the capacity is still low, especially in the central Rift Valley region of the country (CIP, 2011; Demo et al., 2016). Documented studies for mitigating the shortage of quality seed have focused on rapid multiplication technologies, such as aeroponics, hydroponics and tissue culture (apical rooted cuttings) (Muthoni et al., 2011; WasilewskaNascimento et al., 2020). Such methods are limited to the formal seed system due to stringent certification rules stipulated by the Kenya Plant Health Inspectorate Service (KEPHIS). On the other hand, the semi-formal sector, through guidance from trained agricultural officers, has potential for improving the supply of and access to clean seed potato through a decentralised CSPMAE (Chindi et al., 2017; Okello et al., 2018).

Clean seed refers to the first generation of seed potato produced from certified seed potato by trained farmers, through guidance of trained agricultural officers, although not legally recognised by KEPHIS. Contrastingly, there is low uptake of decentralised CSPMAE among potato farmers, resulting into unsatisfied demand for quality seed potato (Kaguongo et al., 2014; KEPHIS, 2016). 
Even though salient studies have been done on adoption of new agricultural technologies, majority consider adoption as a binary decision, hence, limiting the respondents from revealing their gradual willingness to adopt a technology. Lemken et al. (2017), in a study on adoption tendency of mixed cropping, applied the Trans-Theoretical Model (TTM) of behaviour change by capturing adoption in four stages, i.e., pre-contemplation, contemplation, preparation and action) of increasing willingness to adopt. Klonek et al. (2015) earlier proposed the need to apply TTM to understand reasons why individuals were hesitant to exploit entrepreneurship opportunities. Identification of individual's entrepreneurial development stages (adoption tendencies/stage of change) might be key in application of stage-matched interventions, rather than imposing similar intervention for all individuals. Profiling of adopter (action stage) characteristics can also guide in selection of potential individuals for entrepreneurial uptake.

Networking approach to entrepreneurship posits that network resources, activities and networks support are vital for enterprise establishment. Bengesi and Roux (2014) consider networking as a necessary entrepreneurial capability, that can ease development and utilisation of linkages to gain access to resources, knowledge and complementary assets at minimal transaction costs, hence, improving enterprise performance. Parida et al. (2017) established that entrepreneur's networking capability (partner knowledge, relational skills, coordination skills, internal communication, and building new relations) had the potential to enhance SMEs performance. Demo et al. (2016) and Almekinders et al. (2019) proposed the need for seed potato multiplication agripreneurs to develop linkages with other stakeholders in the potato value chain. However, the role of networking capability attributes on establishment of seed potato multiplication agri-enterprises is not clear. This study, therefore, sought to determine the role of entrepreneurs networking capabilities, socioeconomic and institutional factors on adoption tendency of the decentralised clean seed potato businesses (CSPMAE) in Central Valley of Kenya.

\section{METHODOLOGY}

Study site and data collection. The study was conducted in Nakuru County, located within the Central Rift valley region of Kenya in the year 2019. Specifically, Nakuru County is located between Longitude $35^{\circ} 28^{\circ}$ and $35^{\circ}$ $36^{\circ}$ East and Latitude $0^{\circ} 13^{\prime}$ and $1^{\circ} 10^{\prime}$ South, at about 1848 to 2700 metres above sea level (CIDP, 2018). It is the second leading County in potato production in the country, with only three formal certified seed potato-producing merchants (Kibe et al., 2018). Shortage of quality seed potato is amajor challenge to potato farmers in the County. Three sub counties; namely, Kuresoi North, Kuresoi South and Molo were selected for the study due to their dominance in potato farming (CIDP, 2018).

A multistage sampling technique was used in selecting the three sub-counties and 10 wards based on guidance from Sub-County agricultural officers. A cross-sectional survey was conducted using a researcher-administered semi-structured questionnaire, to obtain primary data from 246 potato farmers. The questionnaire was pre-tested among 30 randomly selected potato farmers in Mau Narok and Mauche wards of Njoro SubCounty, which had similar characteristics as the study sites.

The total sample size 246, was computed using Cochran's (1963) formula due to the unknown population of ware potato farmers in the study area. The formula was harmonised following Singh and Masuku (2014) recommendation for adjusting the degree of variability in situations where majority of the population lacked the desired attributes. These farmers constituted 54 clean seed potato 
multiplication agri-preneurs (CSPMA) and 192 non-CSPMA, who were producing ware potato. Because clean seed potato multiplication agripreneurs (CSPMA) were only 54, they were all picked from the 10 wards using snow balling procedure, with guidance from agricultural extension officers. The remaining 192 were randomly selected from the 10 wards based on disproportionate distribution of 54 CSPMA in each ward.

Data analysis for adoption tendencies of clean seed potato multiplication agrienterprise. Ordered logistic regression was preferred due to ordinal categorical nature of the dependent variables (Table 1). These categories included pre-contemplation stage (coded one), contemplation stage (coded two), preparation stage (coded three) and action stage (coded four). The categories symbolised increasing levels of contemplating behavioural change based on the trans-theoretical model. The stages of change captured the gradual attitudes in adoption decision towards CSPMAE and were adapted from Lemken $e t$ al. (2017) study.

The TTM is particularly essential in studies seeking stage-matched interventions, contrary to introducing similar interventions for the entire population (Prochaska and Velicer, 1997). In the present study, identification of characteristics for CSPMA could guide in identification and selection of potential farmers who can be targeted for CSPMAE, especially those in the preparation stage of change (Klonek et al., 2015).

The questionnaire had specific questions that guided the researcher as well as the respondents in selecting their respective stage of change (adoption tendency). For instance, farmers in the pre-contemplation stage constituted all respondents who reported to have no information about clean seed and had never used it to produce their ware potatoes. Such farmers had no motivation to change, hence were not willing to take up CSPMAE. The contemplation stage constituted all respondents who reported to know clean seed 
potatoes; they had used it to produce their ware potatoes and further considered clean seed potato multiplication as an entrepreneurial opportunity due to inadequate supply and access of certified and clean seed at planting season. However, they had no plans of taking up the CSPMAE, in the short run, due to perceived costs involved.

The farmers in the preparation stage involved all respondents who reported to know clean seed and had used it to produce their ware potatoes. They also considered clean seed potato multiplication as a beneficial business opportunity and had access to sufficient information, resources and plans for taking up the CSPMAE in the short run (less than six month).

The action stage constituted all farmers who had taken up the clean seed potato multiplication agri-enterprise and were recognised as clean seed potato agri-preneurs by their fellow farmers and Sub-County agricultural officers.

Given the four choices, a respondent selected a stage based on description of his stage of adoption as shown in Table 1. The selected explanatory variables, their measurement and hypothesised effect are shown in Table 2

Networking Capability (NC) had five latent variables (Table 2), each with three indicators (questions) that were administered to respondents and measured on a five point Likert scale. Confirmatory Factor Analysis (CFA) was used to test consistency of the NC latent variable indicators. The NC data had overall Kaiser-Meyer-Olkin measure of sample adequacy of 0.903 , scale reliability coefficient $(\alpha)$ of 0.8983 and a significant Bartlett's Test value of 0.000 which was adequate for subjecting it to CFA. The factor loading values for the 15 indicator variables ranged from 0.434 to 0.825 . The five constructs of $\mathrm{NC}$ had Composite Reliability (CR) and Average Variance Extracted (AVE) values ranging between 0.551 and 0.811 , and 0.292 and 0.589 , respectively. This was a satisfactory indicator for convergent validity and reliability of the constructs, except for the construct relational skills which had a low AVE of 0.292 and CR of 0.551 that is, lower than the recommended AVE $>0.5$ and $C R>0.6$; hence was exempted in further analysis (Harun and Ahmad, 2016). The scores for each of the NC latent variable were generated using the weighted means then used for further analysis in the ordered logistic regression.

Statistical and specification diagnostic tests. Prior to running Ordered Logistic Regression analysis, the data were subjected to multicollinearity, Heteroskedasticity, and Proportional Odds Diagnostic tests. Multicollinearity was tested using pair-wise correlation and Variance inflation Factor (VIF) for the categorical and continuous explanatory variables, respectively. The mean VIF was 1.45, not exceeding 5.0 as shown in Table 3, implying absence of correlation among the explanatory variables (Jamal, 2017). Harun and Ahmad (2016) postulate that correlation $>0.75$ indicates high correlation. The pair-wise correlation for the categorical independent variable did not exceed 0.75 (Table 5), signifying absence of correlation.

The White test for Heteroskedasticity results in Table 4 had an insignificant value $(P$ $=0.1025)$, indicating that the variance of the error term for the variables was constant, hence no Heteroskedasticity (Williams, 2020). The insignificant overall Chi-square value $\left(\mathrm{P}>\mathrm{chi}^{2}=1.0000\right)$ for Brant test indicated that the proportional odds assumption was not violated, hence qualifying the data for ordered logistic regression (Williams, 2019). The ordered logistic model fitness results presented in the panel of Table 7 showed a good model fit with McFadden's Pseudo R-squared (Pseudo $\mathrm{R}^{2}$ ) of 0.3316 , indicating a stronger exploratory power of the model.

\section{RESULTS AND DISCUSSION}

The descriptive statistics for adoption tendencies (stages of change) revealed that $53 \%$ (131) of the farmers were in pre- 
TABLE 2. Selected independent variables for ordered logistic regression for a study on clean seed potato multiplication agri-enterprises in the central Rift Valley, Kenya

Definition of explanatory variable and its measurement

Expected sign

Agri-preneur socio-economic characteristics Age of the household head (HHH) in years (continuous)

Gender of the $\mathrm{HHH}$, (dummy $1=$ male, $0=$ female $)$

Education level of the $\mathrm{HHH}$, categorical, 1 = none, 2 = primary, $3=$ secondary, 4 = college/university, $5=$ others

Total land size owned by the household in hectares (continuous)

Size of land allocated for potato by household in Ha (continuous)

Type of land ownership 1= Own with title deed, 0 otherwise.

Number of dependents in the household. (Continuous)

Off farm sources of income. $1=$ have other sources, $0=$ otherwise.

Agri-enterprise enabling institutional characteristics. Number of contacts with extension service providers in 2018 (Continuous).

Participation in potato contract farming ( 1 if yes, 0 otherwise)

Number of contacts with certified seed producer in 2018. (Continuous)

Ownership of storage facility by household (1if yes, 0 otherwise)

Ownership of transport means by household (1 if yes, 0 otherwise)

Membership of HHH to potato related group ( 1 if yes, 0 otherwise). Entrepreneurial Networking capability related factors

Relational skills of the $\mathrm{HHH}$ with other value chain actors/employees*

Partner knowledge of the $\mathrm{HHH}^{*}$

Internal communication of the HHH with employees*

Coordination skills of the HHH with partners and employees*

Ability of the $\mathrm{HHH}$ to build new relationships*

'Networking capability dimensions (*) were adapted from studies by Bengesi and Roux (2014) and Parida et al. (2017) 
TABLE 3. Variance inflation factor test for continuous independent variables in Ordered Logistic Regression model

\begin{tabular}{lll}
\hline Variable & VIF & $1 /$ VIF \\
\hline Coordination skills (CS) & 2.01 & 0.4987 \\
Building new relations (BNR) & 1.85 & 0.5407 \\
Internal communication (ICM) & 1.63 & 0.6130 \\
Interaction with certified seed producer & 1.48 & 0.6761 \\
Partner knowledge (PKW) & 1.39 & 0.7187 \\
Interaction with extension officers & 1.35 & 0.7405 \\
Age of household head & 1.15 & 0.8694 \\
Household size & 1.11 & 0.9007 \\
Land allocated potatoes & 1.09 & 0.9169 \\
& &
\end{tabular}

$\mathrm{VIF}=$ variance inflation factor; $1 / \mathrm{VIF}=1 /$ variance inflation factor

TABLE 4. Heteroskedasticity White test for the independent variables involved in the study about clean seed potato multiplicationin the central Rift Valley, Kenya

\begin{tabular}{lrrc}
\hline Source & $\mathrm{Chi}^{2}$ & Df & $\mathrm{P}$ \\
\hline Heteroskedasticity & 186.25 & 163 & 0.1025 \\
Skewness & 30.83 & 17 & 0.0210 \\
Kurtosis & 1.90 & 1 & 0.1681 \\
Total & 218.97 & 181 & 0.0284 \\
\hline
\end{tabular}

contemplation stage, hence not willing to try CSPMAE (Table 6). About 15\% (37) were in contemplation stage with only $10 \%$ (24) in preparation stage (willing to take up the CSPMAE in short run); while the remaining $22 \%$ (54) were practicing CSPMAE hence in action stage.

Influence of agri-preneur networking capability. It is clear from the ordered logit results (Table 7) that partner knowledge of the household head, a construct of networking capability, positively influenced the adoption tendency of CSPMAE (1\% significance level). An increase in the score of partner knowledge led to 1.56 increase in the log odds of being in a higher stage of CSPMAE adoption tendency. Partners' knowledge is among the necessary networking capability attributes that enable an individual to identify partners with relevant capabilities and resources to complement their needs for better performance of their enterprises, as postulated by Bengesi and Roux (2014). Entrepreneurs with better partner knowledge attributes can also avoid enterprise instability resulting from partnership disputes. Therefore, farmers with stronger partner knowledge have better networks and linkages with other actors in the potato value chain, hence, enhancing their capacity to be in higher stage of CSPMAE. This was consistent with previous findings of positive 
impact of entrepreneur networking capability on SMEs performance (Bengesi and Roux, 2014; Ajayi, 2016).

The empirical results also indicates a positive insignificant effect of building new relations on adoption tendency. However the internal communication and coordination skills dimensions of NC had a negative influence on adoption tendency of CSPMAE (Table 7). This is contrary to priori expectations of the study, although Bengesi and Roux (2014) in their study also found a negative influence of coordination skills on SME performance in Tanzania. There is limited literature to conclusively ascertain the relationship between networking capability and adoption tendencies, since most studies have focused on the influence of $\mathrm{NC}$ of firm performance and innovativeness. Further studies would, therefore, help to substantiate the relationship between networking capability and agricultural entrepreneurial adoption tendency.

Influence of agri-preneur socio-economic characteristics. Among the socio-economic aspects of the household head, gender, land allocated to potato and level of education had a positive influence on adoption tendencies of CSPMAE (Table 7). Being a male farmer increased the log odds of being in higher adoption tendency stage of CSPMAE by 0.65 , as compared to female farmers, ceteris paribus (Table 7). This could be attributed to gender roles defined by the society, whereby male gender is less confined to domestic jobs, hence giving them freedom to participate in several meetings and trainings, as postulated by Wang et al. (2017). Such meetings may involve dissemination of useful information, which probably enhanced their uptake of CSPMAE. According to Rola-Rubzen et al. (2020), social-cultural values and norms give men authority over decision-making and ownership of productive resources such as land. This could have enhanced their adoption of seed multiplication agri-enterprise as compared to women.These findings are consistent with Wang et al. (2017), whose study found a 
TABLE 6. Distribution of farmers in various stages of change

\begin{tabular}{lcr}
\hline Stage of change & Frequency & Percentage (\%) \\
\hline Pre-contemplation & 131 & 53.25 \\
Contemplation & 37 & 15.04 \\
Preparation & 24 & 9.76 \\
Action & 54 & 21.95 \\
Total & 246 & 100.00 \\
\hline
\end{tabular}

TABLE 7. Factors influencing adoption tendency of clean seed potato multiplication agri-enterprises in central Rift Valley, Kenya

\begin{tabular}{|c|c|c|c|}
\hline Stage of change/adoption tendency & Coefficient & Std. Err. & $\mathrm{P}>\mathrm{Z}$ \\
\hline \multicolumn{4}{|c|}{ Agri-preneur networking capability characteristics } \\
\hline Internal communication (ICM) & -0.1158 & 0.2099 & 0.581 \\
\hline Partner knowledge (PKW) & $1.5581 * * *$ & 0.2564 & 0 \\
\hline Building new relations (BNR) & 0.2593 & 0.3116 & 0.405 \\
\hline Coordination Skills (CS) & -0.122 & 0.3127 & 0.696 \\
\hline \multicolumn{4}{|c|}{ Agri-preneur socio-economic characteristics } \\
\hline Gender of household head & $0.6510^{*}$ & 0.3493 & 0.062 \\
\hline Age of household head & -0.0133 & 0.013 & 0.305 \\
\hline Household Size & -0.122 & 0.0739 & 0.099 \\
\hline Land allocated to potato & $0.1779 * * *$ & 0.0551 & 0.001 \\
\hline Land ownership type & 0.2738 & 0.3252 & 0.4 \\
\hline Level of education of household head & $0.6172 * * *$ & 0.2182 & 0.005 \\
\hline Off farm income participation & 0.3915 & 0.3728 & 0.294 \\
\hline \multicolumn{4}{|c|}{ Agri-enterprise enabling institutional characteristics } \\
\hline Ownership of storage & $1.0193 * * *$ & 0.329 & 0.002 \\
\hline Ownership of transport & $1.7819 * * *$ & 0.5466 & 0.001 \\
\hline Membership to potato group & 0.5445 & 0.337 & 0.106 \\
\hline Participation in contract farming & -0.4904 & 0.4365 & 0.261 \\
\hline Interaction with extension officers & $0.1755^{*}$ & 0.094 & 0.062 \\
\hline Interaction with certified seed producer & $0.6208 * * *$ & 0.1201 & 0 \\
\hline 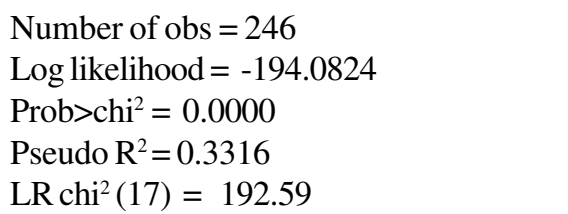 & & & \\
\hline
\end{tabular}

$*$ and $* * *$ depicts $10 \%$ and $1 \%$ significance levels, respectively 
positive influence of gender on adoption of hybrid maize in Kenya. Mwangi and Kariuki (2015) in their review of factors determining adoption of new agricultural technology by smallholder farmers in developing countries, also cited a positive influence of gender on adoption. This empirical findings indicates a significant role of gender in adoption tendency of CSPMAE. Amendment of gender equity and equality is, therefore, necessary for enhancing uptake of CSPMAE by female farmers too.

The size of land allocated for potato production significantly influenced the adoption tendency of CSPMAE $(\mathrm{P}<1 \%)$ (Table 7). A unit increase in size of land allocated for potato, ceteris paribus, leads to 0.18 increase in log odds of being in a higher stages of CSPMAE adoption tendency. Land is a crucial resource in clean seed potato multiplication (KEPHIS, 2016). Large farm size facilitates crop rotation, which helps to uphold the quality of seed against diseases such as bacterial wilt (Wasilewska-Nascimento et al., 2020). Farmers with large land parcels, therefore, had relatively sufficient resources mandatory for participation in CSPMAE; compared to farmers with lower land acreage. Ownership of resourceful assets such as land was, therefore, an incentive to adopt agri-entrepreneurial opportunities such as clean seed potato multiplication. Onyeneke (2017) and Kapalasa et al. (2019) consistently found a positive influence of farm size in their adoption studies. Therefore, consideration of farmers with larger land acrage is key for projects seeking to recruit farmers into CSPMAE, rather than targeting all farmers. This findings suggests the significant role of land in adoption tendency of clean seed agri-enterprises in the Central Rift Valley in Kenya.

Level of education of the household head also influenced the uptake stage of CSPMAE (Table7); suggesting that acquiring higher level education from college or university leads to 0.62 increase in log odds of being in a higher stage of adoption tendency of CSPMAE, ceteris paribus. This is consistent with the results of Wang et al. (2017), who abserved that farmers with college and higher education levels had a higher probability of adopting hybrid maize; and concluded that educated farmers were more likely to purchase hybrid seed and observe agronomic practices. Educated farmers tend to have comparatively greater access to information than their illiterate counterparts, thus increasing their level of awareness to new technology and entrepreneurial opportunities. Awareness likely enhances the adoption tendencies of CSPMAE, compared to lower awareness among farmers with lower level of education (Mwangi and Kariuki, 2015). Consequently, enhancement of capacity building among interested farmers in lower stages of adoption tendency and selection of educated farmers is a crucial intervention for engaging in CSPMAE.

Influence of agri-enterprise enabling institutional characteristics. Ownership of storage facility significantly influenced the stages of change of CSPMAE (Table 7) leading to a 1.02 increase in log odds of being in higher stages of adoption tendency for CSPMAE. Storage facility is a vital requirement in maintaining the quality of seed potato (Muthoni et al., 2015). It aids in prevention of postharvest losses associated with storage, such as rotting, greening and unnecessary sprouting of tubers due to short dormancy (Muthoni et al., 2015). Farmers who owned storage facility were, therefore, more likely to be in the action stage of adoption tendency of CSPMAE, as compared to those without stores. Moreover, buyers are sensitive to the quality of seed, hence making storage facility a crucial requirement for CSPMAE. Ownership of storage facility, therefore, plays a vital role in adoption tendency of clean seed multiplication agri-enterprises. Targeting farmers with such profile, could increase the uptake of clean seed potato entrepreneurial opportunities. 
Similarly, ownership of transport facility influenced the uptake stages of CSPMAE at $\mathrm{P}<1 \%$ (Table 7). Owning a transport facility increased the log odds of being in a higher stage of adoption tendency for CSPMAE by 1.78. This means that farmers who owned transport had a higher probability of adopting clean seed potato multiplication agrienterprises, than those without such infrastructure. Ownership of transportation assets such as motorcycle, vehicle or donkey cart facilitates efficient and effective mobility of farm inputs and outputs between the farm and the markets. This helps to reduce transaction costs incurred by the farmers. Due to the bulky nature of seed potato and their high demand during planting season, farmers who own transportation facilities were more likely to be in the higher stages of adoption tendency of CSPMAE compared to farmers without own transport means. Additionally, CSPMAE requires investment of bulky inputs such as certified seed and fertiliser, hence ownership of transport facilitates easy transportation from the market to remote areas (Muthoni et al., 2013). Thus, ownership of transport plays a significant role in adoption tendency of CSPMAE hence a crucial trait when profiling farmers to participate in CSPMAE.

Interaction of the household head with extension officers had a positive significant influence on adoption tendency of CSPMAE (Table 7). A unit increase in number of interaction with agricultural extension officer increased the log odds of being in a higher stage of adoption tendency for CSPMAE by 0.18 . Agricultural extension officers are equipped with agricultural knowledge and training skills, hence are useful human capital in dissemination of information (KEPHIS, 2016). Farmers who interacted frequently with such change agents seem to have gained more valuable information about clean seed potato multiplication, hence motivating them to take up the entrepreneurial opportunities. Kalibwani et al. (2017) and Lasway et al. (2020) consistently found a positive effect of access to extension services on adoption of soil conservation technologies in east Africa. Due to its significant role in CSPMAE adoption tendency, employment and facilitation of more agricultural extension officers by the County Government would help to enhance diffusion of knowlegde to farmers.

Access to certified seed positively influenced the uptake of CSPMAE (Table 7). A one unit increase in frequency of interaction with certified seed potato producers, increased the log odds of being in the higher stages of adoption tendency by 0.62 . Farmers who got access to certified seed had higher propensity of taking up CSPMAE, compared to those without access ceteris paribus. Certified seed is scarce, but a crucial requirement in production of clean seed (WasilewskaNascimento et al., 2020). Due to its scarcity, those farmers who interacted with the certified seed producers were frequently likely to get access to certified seed, hence gaining an advantage to participate in CSPMAE, compared to other farmers who did not interact with certified seed producers. Since certified seed plays a significant role in the adoption tendency of CSPMAE, the formal sector should increase their production capacity for enhanced supply of certified seed among the potential clean seed potato multiplication agri-preneurs.

\section{CONCLUSION}

It is clear from this study that among the networking capability constructs, partner knowledge of the household head and their ability to build new relations play a positive role in adoption tendency of CSPMAE in the central Rift Valley of Kenya (Nakuru). Gender of the household head, land allocated to potato and level of education of the household head are among the socio-economic factors that positively influence the uptake stages for decentralised CSPMAE in this region. Major institutional factors include ownership of 
transport, ownership of storage facility, interaction with extension services and interaction with certified seed potato producer; all of which had effects on adoption tendencies of decentralised CSPMAE in the study area.

\section{ACKNOWLEDGMENT}

The authors are grateful to the MasterCard Foundation and Regional Universities Forum for Capacity Building in Agriculture (RUFORUM) for funding research and publication cost through the Transforming African Agricultural Universities to meaningfully contribute to Africa's growth and development (TAGDev) Program. The seed potato Community Action Research Project+ (CARP+) is also appreciated for linking the researcher to stakeholders in the potato sector which facilitated identification of community challenges.

\section{REFERENCES}

Ajayi, B. 2016. The impact of entrepreneurial orientation and networking on the export performance of Nigerian agricultural SMEs. Journal of Entrepreneurship and Innovation in Emerging Economies 2(1): 1-23.

Almekinders, C.J., Kim, J., Andrade, J., McEwan, M., Haan, S. D., Kumar, L. and Staver, C. 2019. Why interventions in the seed systems of roots, tubers and bananas crops do not reach their full potential. Food Security 11(10):23-42.

Bengesi, K.M. and Roux, I.L. 2014. The influence of dimensions of networking capability in small and medium enterprise performance. International Journal of Business and Social Science 5(2):189-200.

Chindi, A., Shunka, E., Atsede, S., Giorgis, G.W., Seid, E. and Tessema, L. 2017. Participatory potato seed production: A break through for food security and income generation in the central highlands of Ethiopia. Open Agriculture 2(1):205-212.
CIDP. 2018. Nakuru: County intergrated development plan (2018-2022).https:// roggkenya.org/wp-content/uploads/ Nakuru_CIDP_2018-2022_CountyIntegrated-Development-Plan.pdf.Retrived March 13, 2019.

CIP. 2011. Roadmap for investment in the seed potato value chain in Eastern Africa. Lima Peru: The U.S. Agency for International Development. http://cipotato.org/wpcontent/uploads/2014/05/CIP_RoadmapFinal.pdf.Retrived October 1, 2018.

Cochran, W.G. 1963. Sampling techniques. Second edition, Wiley and sons Inc., New York, USA.

Demo, P., Lemaga, B., Kakuhenzire, R., Schulz, S., Borus, D., Barker, I. and Schulte-Geldermann, E. 2016. Potato and sweetpotato in Africa: Transforming the value chains for food and nutrition security. Strategies to improve seed potato quality and supply in Sub Saharan Africa: experience from interventions in five countries, CABI International. pp. 155-167.

Government of Kenya. 2017. The big four Immediate priorities and action. In: GOK, Food and nutrition security. pp. 9-15. Government of Kenya. https://npck.org/ Books/GovernmentofKenyaBigFour.pdf. Retrived March 13, 2019.

Harun, M.S. and Ahmad, S. 2016. Factor structure, reliability and validity of attitudes of biostatistics scale. British Journal of Mathematics and Computer Science 16:19.

Jamal, D. 2017. Multicollinearity and regression analysis. Journal of Physics: Conference series. pp. 1-7.

Kaguongo, W., Maingi, G., Barker, I., Nganga, N. and Guenthner, J. 2014. The value of seed potatoes from four systems in Kenya. American Journal of Potato Research 91(1):109-118.

Kalibwani, R.M., Kakuru, M.,Kamugisha, R., Twebaze, J., Hilman, E.,Tumuheirwe, H., Tenywa, M.M.,Nyamwaro, R.O.,Mugabo, J., Buruchara, R; Fatunbi, A.O. and 
Adekunle, A. 2017. Adoption of soil conservation through collective actions in SouthWestern Uganda. African Crop Science Journal 25(1):13-19.

Kapalasa, E., Demo, P., Nyekanyeka, T.T. and Okero, J. 2019. Assessing factors influencing farmers adoption of improved potato varieties in Malawi. International Journal of Economy, Energy and Environment 4(1):1-10.

Kenya Plant Health Inspectorate Service. 2016. Seed potato production and certification guidelines. Nairobi: KEPHIS. http:// www.kephis.org/images/docs/seedpotato booklet.pdf Retrieved October 1, 2018.

Kibe, A.M., Mwangi, M., Kaguongo, W. and Kaguora, E. 2018. Potato project to unlock potential of crop in the rift. https:// www.nation.co.ke/business/seedsofgold/ Potato-project-to-unlock-potential-of-crop/ 2301238-4721374-e2v2bvz/index.html. Retrieved December 12, 2018

Klonek, F.E., Isidor, R. and Kauffeld, S. 2015. Different stages of entrepreneurship: Lessons from the transtheoretical model of change. Journal of Change Management 15(1):43-63.

Lasway, J.A., Temba, G.R. and Ruhinduka, D.R. 2020. Determinants of soil conservation technologies among smallscale farmers in Tanzania. Evidence from National Panel Survey. African Journal of Economic Review 8(1):89-104.

Lemken, D., Spiller, A. and von Meyer-Höfer, H. M. 2017. The case of legume-cereal crop mixtures in modern agriculture and the transtheoretical model of gradual adoption. Ecological Economics 137:2028.

Louwaars, N.P. and De Boef, W.S. 2012. Integrated seed sector development in Africa: A conceptual framework for creating coherence between practices, programs, and policies. Journal of Crop Improvement 26(1):39-59.
National Potato Council of Kenya. 2020. Acute Seed Potato Shortage.https://npck.org/ news/

McGuire, S. and Sperling, L. 2016. Seed systems smallholder farmers use. Food Security 8(1):179-195.

Muthoni, J., Mbiyu, M. and Kabira, J. 2011. Upscaling of certified potato seed tubers in Kenya: Potential of aeroponic technology. Journal of Horticulture and Forestry 3(8):238-243.

Muthoni, J., Shimelis, H. and Melis, R. 2013. Potato production in Kenya: Farming systems and production constraints. Journal of Agricultural Science 5(5):182.

Muthoni, J., Kabira, J.N., Kipkoech, D., Abong, G.O. and Nderitu, J.H. 2015 prolonging the shelf life of seed potato at farm level: Cold storage or diffused store? International Journal of Horticulture 5(13): $1-4$.

Mwangi, M. and Kariuki, S. 2015. Factors determining adoption of new agricultural technology by smallholder farmers in developing countries. Journal of Economics and Sustainable Development 6(5):208-216.

Okello, J.J., Zhou, Y., Kwikiriza, N., Ogutu, S., Barker, I., Geldermann, E.S., Atieno, E. and Ahmed, J.T. 2017. Productivity and food security effects of using of certified seed potato: The case of Kenya's potato farmers. Agriculture and Food Security 6(25):1-9.

Okello, J., Jogo, W., Kwikiriza, N. and Muoki, P. 2018. Motivations and cognitive models associated with decentralized seed multiplication: Experience from bio fortified sweet potato vine multipliers in Kenya and Ethiopia. Journal of Agribusiness in Developing and Emerging Economies 8(4): 626-641.

Onyeneke, R.U. 2017. Determinants of adoption of improved technologies in rice production in Imo State, Nigeria. African Journal of Agricultural 12(11):889-896. 
Parida, V., Pesäma, O., Wincenta, J. and Westerberg, M. 2017. Network capability, innovativeness, and performance: A multi dimensional extension for entrepreneurship. Journal of Entrepreneurship and Regional Development 29(1-2):94-115.

Prochaska, J.O. and Velicer, W.F. 1997. The transtheoretical model of health behavior change. American Journal of Health Promotion 12(1):38-48.

Rola-Rubzen, M.F., Paris, T., Hawkins, J. and Sapkota, B. 2020. Improving gender participation in agricultural technology adoption in Asia: From rhetoric to practical action. Applied Economic Perspectives and Policy 42(1):113-125.

Singh, A.S. and Masuku, M.B. 2014. Sampling techniques and sample size determination in applied statistics research: An overview.
International Journal of Economics, Commerce and Management 2(11):1-22.

Wang, Y., Vitale, J., Park, P., Adams, B., Egesa, B. and Korir, M. 2017. Socioeconomic determinants of hybrid maize adoption in Kenya. African Journal of Agricultural Research 12(18):617-631.

Wasilewska-Nascimento, B., Mánkowska, D. B. and Zarzy Nska, K. 2020. Challenges in the production of high-quality seed potatoes (Solanum tuberosum L.) in the tropics and subtropics. Agronomy 10(2):260.

Williams, R. 2019. Ordered Logit Models University of Notre Dame.https://www3. nd.edu/ rwilliam/xsoc73994/Ologit01.pdf. Accessed 3rd February 2020.

Williams, R. 2020. Heteroskedasticity University of Notre Dame. https://www3. nd.edu/ rwilliam/stats2/125.pdf Accessed 3rd February 2020. 